\title{
The Reasons of School Dropouts in Higher Education: Babaeski Vocational College Case
}

\author{
Ertug Can ${ }^{1, *}$, Fatma Oya Aktas², Isil Tuzun Arpacioglu ${ }^{3}$ \\ ${ }^{1}$ Department of Educational Sciences, Faculty of Science and Literature, Kirklareli University, Turkey \\ ${ }^{2}$ Department of Foreign Trade, Babaeski Vocational College, Kirklareli University, Turkey \\ ${ }^{3}$ Department of Banking and Insurance, Babaeski Vocational College, Kirklareli University, Turkey
}

Copyright $\bigcirc 2017$ by authors, all rights reserved. Authors agree that this article remains permanently open access under the terms of the Creative Commons Attribution License 4.0 International License

\begin{abstract}
In Turkey, nearly 400.000 higher education student have left university education in the last 3 years. This figure is an indication of a negative situation. Turkey is in the first place in terms of school dropout rates within the European Higher Education Area (EHEA). After completing primary and secondary education and passing the necessary exams, high figures belonging to students who are placed in a higher education program but who terminate their education on various occasions must be justified. The research was carried out between March 2016 and June 2017 in order to create a projection about reasons for the school dropout with the participation of Kirklareli University Babaeski Vocational College students who requested the 'registration clearance'. According to research results, students usually ask for registration clearance for financial reasons. The research findings are important in terms of determining the causes of school dropouts at higher education level in Turkey and suggesting solution proposals. In order to prevent school dropouts at the higher education level, especially at vocational colleges, there is a need to establish an effective system for students, instructors and administrators.
\end{abstract}

Keywords School Dropouts Rates, European Higher Education Area (EHEA), Effective Guidance and Counseling System

\section{Introduction}

The number of universities in Turkey is increasing day by day. There are a total of 179 universities, including 65 foundation universities, 114 state universities and 6 vocational colleges in Turkey (CoHE, 2017). Although the number of universities increase the number of the choices of the candidates, the lack of information or the lack of research after the registration, and the situations that arise after enrolling in the university, cause the students to break their relations with the universities. In order to eliminate the lack of knowledge and research, students should be informed well at the level of primary and secondary education (Tayli, 2008). In addition, differences in school dropouts between higher education levels and primary and secondary education levels should not be overlooked. This research is the first step in the work to be done in this regard to find out the reasons for school dropouts. The solution suggestion can only be made after the causes of the problems have been identified.

There are various classification systems in the researches on school causes of the cause. The research about school dropouts is divided into three basic types; temporary leaves, leaving the institution, abandoning the education system (Bulbul, 2012), especially in terms of leaving the institution and abandoning the education system. Among those students there are those who want to go to another school (leave the institution) as well as those who leave the university for good (those who abandoned the system) (Chen, 2008).

Comprehensive research on school drop-outs has increased, especially in developed countries, due to the need to invest more in human resource development, which is of importance in both education and economy/industry. For example, Europe 2020, a 10-year economic progress strategy of the European Union in 2010 , targeted $40 \%$ of EU citizens aged $30-34$ years to complete higher education. It is aimed by Europe 2020 reducing the level of "school dropouts" and ensuring that EU citizens settled in a higher education program are able to complete the program and acquire the necessary competencies in order to meet the labor force needs of the information- intensive sectors and to provide social justice (EU, 2015: 7). Within this context, which is of great importance in terms of economic 
development and sustainability, the European Union has drawn up a comprehensive report on school dropouts, causes and solutions. With the problem becoming visible in Turkey, researches have increased and strategies have begun to be developed. The vast majority of these surveys are institutional / university based.

The aim of this research is to determine the reasons for school dropouts in higher education and to develop recommendations for preventing school dropouts.

\section{Method}

The research group is composed of registered students in Kirklareli University Babaeski Vocational College who required registration clearance between March 2016 and June 2017. The data of the research were provided by face to face and telephone interview by means of a standard form using quantitative and qualitative research methods. Official national data was also used. Demographic data and quantitative research data were evaluated with the means of percentage and frequency. The analysis of the data was done with the help of descriptive analysis and content analysis. Contents analysis has been followed to organize the data to read the whole data in order to make a general sense and to take notes, to define the data, to classify and interpret the data, to present the findings (Creswell and Clark, 2011). Qualitative research can be defined as qualitative data collection methods such as observation, interviews and document analysis, and a qualitative process for revealing perceptions and events in a natural and realistic way (Yildirim and Simsek, 2013: 45).

In the research, case studies method was used from qualitative and quantitative research designs. Thus, it was attempted to obtain explanatory information on school abandonment. Within the scope of the research, maximum variation sample was used from purposeful sampling methods. According to Yildirim and Simsek (2013); the goal of using the maximum variation sampling is to create a relatively small sample and reflect the diversity of the individuals that may become the party in this sample to the maximum extent.

As a result of analysis of open-ended questions in the research, 6 themes were obtained. These include: economic, family, request to register with another school, health, military service and others. Qualitative research data have been examined on the basis of these themes. Furthermore, in the "Consultant Opinion" section of the form, the students who prefer to do so explained the reasons behind their register clearance requests. Within this data, the gender, the program to which they are affiliated, the status of normal or evening education, and the reasons for the registration clearance are also examined.

\section{Findings}

According to findings, between March 2016 and June 2017, 116 students who had requested a register clearance in Kirklareli University Babaeski Vocational School was processed. $54 \%$ of the participants were male and $46 \%$ were female. $62 \%$ of the participants have failed in the classes they took and they are repeating the classes. $23 \%$ (27 of them) are evening education students.

Table 1. The Reasons Behind School Dropouts, Gender Based

\begin{tabular}{ccccc}
\hline Reasons & Female & Male & Total & \% (Appr.) \\
\hline $\begin{array}{c}\text { Request to register with another } \\
\text { school }\end{array}$ & 30 & 31 & 61 & 53 \\
Economic & 3 & 13 & 16 & 14 \\
Familial & 8 & 3 & 11 & 9 \\
Health & 0 & 0 & 0 & 0 \\
Military Service & - & 4 & 4 & 3 \\
Other & 12 & 12 & 24 & 21 \\
Total & 53 & 63 & 116 & 100 \\
\hline
\end{tabular}

As can be seen in Table 1, among the reasons for registration clearance requests, the most frequently requested is to register with another school by $53 \%$. This is followed by other reasons with $21 \%$, economic reasons with $14 \%$ and family reasons with $9 \%$. If it is distributed according to gender; the participants who declare economic reasons are mostly male, while for family reasons most of the participants are female. There is no student who requests a registration clearance due to health reasons.

Table 2. The Reasons Behind School Dropouts, Program Based

\begin{tabular}{ccccccc}
\hline Reasons/Programs & $\mathrm{BI}^{*}$ & $\mathrm{OM}^{*}$ & $\mathrm{CC} *$ & $\mathrm{FT}^{*}$ & $\mathrm{BA}^{*}$ & $\mathrm{LA}^{*}$ \\
\hline $\begin{array}{c}\text { Economic } \\
\text { Request to register with }\end{array}$ & 6 & 4 & 1 & 0 & 1 & 4 \\
$\begin{array}{c}\text { another school } \\
\text { Familial }\end{array}$ & 17 & 10 & 7 & 13 & 7 & 7 \\
Health & 5 & 2 & 1 & 0 & 1 & 2 \\
Military Service & 0 & 0 & 0 & 0 & 0 & 0 \\
Other & 1 & 1 & 0 & 1 & 1 & 0 \\
Total & 4 & 8 & 1 & 1 & 6 & 4 \\
\hline
\end{tabular}

*BI: Banking and Insurance, OM: Office Management and Executive Assistance, CC: Call Center Services, FT: Foreign Trade, BA: Business Administration, LA: Local Administration

As seen in Table 2, most requests for registration clearance were made in Banking and Insurance (BI) and Office Management and Executive Assistance (OM) programs. This is in line with the facts, first of all, that these two programs are active programs since 2007 , the year Kirklareli University was founded; secondly the high rates of students who cannot complete their studies in two years, and the large number of quotas of these programs. 
Table 3. Babaeski Vocational College, Program Quotas

\begin{tabular}{ccc}
\hline Programs & Quota & \% (Appr.) \\
\hline Banking and Insurance & 150 & 37 \\
Call Center Services & 80 & 19 \\
Local Administration & 80 & 19 \\
Office Management and Executive Assistance & 50 & 12 \\
Foreign Trade & 30 & 7 \\
Business Administration & 20 & 5 \\
Total & 410 & 100 \\
\hline
\end{tabular}

The quota of active programs within the Babaeski Vocational College is shown in Table 3, respectively. The number of enrolled students in the Local Administrations Program with a quota of 80 starting in the academic year 2014-2015 and the Call Center Services Program with a quota of 80 starting in 2015-2016 academic year, is less than that of other programs due to the fact that they are new programs.

Participants were asked to elaborate the reasons for registration clearance request in the "Consultant Opinion" section of the forms used in the research. According to these findings, the reason for a request to register with another school is that the participants want to continue education at a place close to their family or while living with the family, want to continue their education in a place close to the work place, want to continue their education with open and distance education system because they have to work and other.

Table 4. Detailed Reasons for Registration Clearance Request to Register With another School

Female Male Total \%(Appr.)

\begin{tabular}{ccccc}
\hline $\begin{array}{c}\text { Demand to continue } \\
\text { education at a place close to } \\
\text { the family/ while living with } \\
\text { the family }\end{array}$ & 12 & 5 & 17 & 28 \\
$\begin{array}{c}\text { Demand to continue their } \\
\text { education in a place close to } \\
\begin{array}{c}\text { Demand to continue their } \\
\text { education with open and }\end{array}\end{array}$ & 8 & 10 & 18 & 30 \\
Other & 4 & 9 & 13 & 21 \\
Total & 30 & 31 & 61 & 100 \\
\hline
\end{tabular}

As shown in Table 4, when the other option is excluded from the category, among participants who want to keep their education life in another school, the proportion of the ones who do this with economic concerns is $79 \%$ (48 people). As Table 1 shows, the number of respondents who demand registration clearance with direct indication of economic reasons is 16.

\section{Results, Conclusions and Recommendations}

According to the findings of the research; 55\% (64 people) of the participants, among 116 Kirklareli University Babaeski Vocational School students, decided to terminate their education life with the request to register with another school which is mainly due to economic reasons as explained earlier and who due directly to economic reasons. In this respect, college dropouts differ with reasons for dropping out of high school, which mostly manifests itself as student-based (failure, getting bored from school and lessons, absenteeism, emotional attachment to others, various bad-habits, using violence to solve problems, discipline and health problems) (Bayhan, Dalgic, 2012). Only $23 \%$ of the students who want to cancel the registration are enrolled to evening education, therefore it is clear that "education fees" do not hold a great place among these economic reasons since only evening education students pay "semester based education fees". However, students are struggling to meet the costs of housing, nutrition and other education expenditures (such as the course materials, computer and internet access, etc.), and the costs of a university student's social and cultural needs cannot be paid therefore students end their education life. In addition, as a result of the findings, the percentage of students who failed in classes and repeat those classes are $62 \%$. Exceeding the prescribed period of the two-year training returns as a financial burden to the students themselves and to their families. This shows that the failure of the classes affect the financial situation and leads to school dropout.

As a result of the research, as Bennett has formulated, it has been found that the reasons of the registration clearance requests are in the scope of forced abandonment, stemming from the reasons of "many class failures, serious illness, different job opportunities, family problems, financial difficulties, adjustment problems" (Bennett, 2003). Students in this situation usually abandon the education system for good, not just the institution. Unlike the conclusion of this research, for example, Tinto (1975) argues that the most powerful determinant of forced abandonment is the academic performance. As a result of elaborating the research with different methods and expanding its scope, other connections can be revealed with healthier data. In another research on the same topic suggest that measures should be taken for students' problems arising from universities by observing the approaches related to the university management and teaching processes and for more effective solutions, studies should be carried out with the participation of the students who have left university (Simsek, 2013).

The fact that most of the research done in Turkey is mostly on institutional basis and insufficient although it contributes to seeing the big picture about the national dimension of the problem of school dropouts. In this regard, extensive research should be conducted by the relevant government agencies to include the full range of educational system networks. 
For the solution of the problem, studies and solutions proposed by the relevant institutions of other countries can be taken into consideration. For example, a research involving $170 \mathrm{EU}$ higher education institutions, policies and implementations to reduce the rate of school dropouts have generally been grouped under 3 headings: 1) Fund creation and financial incentives 2 ) Information and support for students (counseling, career counseling etc.) 3) Reorganization of higher education, (degrees, quality, accreditation, etc.) (EU, 2015: 8). When these studies are taken as an example, first of all, high school students who will be going to tertiary education should be informed clearly about higher education programs and the requirements, difficulties and financing of higher education and this information should be provided nation-wide (EU, 2015: 93-94). It should not be forgotten that the students who enrolled in a higher education institution and then went to registration clearance caused a loss of resources both institutionally and nationally. Secondly, students who have to withdraw from school due to economic deprivation, lack of scholarship facilities, failure to meet the need for housing, and forced to work should be brought back and enrolled in tertiary education. In this context, the measures that the European Union recommends to be taken can generally be grouped under two main headings and can also be applied within Turkey. First one is to develop nationally conscious national strategies. National policies to be developed in this context should be primarily in the form of allocating or funding education with bigger budget arrangements. Secondly, it should be ensured that high school students who prefer higher education should be informed effectively about the departments of higher education and their detailed pros and cons. Finally, solutions should be implemented under the umbrella of the relevant national institutions in order to organize all these solutions to the relevant parties, including higher education institutions, high school students and students in higher education. The reasons for school dropouts can be elaborated in detail by the Ministry of National Education and the Council of Higher Education, by having continuous information flow about the school dropouts, with a comprehensive and widespread study of the reasons for school dropouts. As a result, it is necessary to develop comprehensive institutional strategies directing by the governing institutions.

Furthermore, according to the OECD's September 2016 report, the budget for education is decreasing every year by more and more governments. As a consequence, on average, $30 \%$ of education costs are derived from individual funds, such as families or students, rather than public funds (OECD, 2016: 29). This suggests that the financial burden of education is increasingly loaded on students and that those who cannot provide financial resources will tend to dropout their education. Since human resources in Turkey are not sustainable under the scope of "unqualified / cheap worker" and knowledge-intensive sectors are considered to be the dominant sectors in all aspects of the economy, investing in high quality human resources becomes really important. In this context, there is a need to focus firstly on the students who drop out of higher education due to financial inadequacies and to take macro level precautions about avoidable "loss of quality human resources".

According to research findings, it is necessary to establish an effective guidance and counseling system for students, instructors and administrators in order to prevent student abandonment at the higher education level, especially at vocational colleges. The findings of the research reveal that secondary education graduates and their families also need an effective guidance and counseling system when they are trying to find the right higher education institutions. In order to avoid school dropouts, it may be useful to develop a quality-oriented, educational-oriented approach and policy in higher education, and work towards the solution of financial problems of students.

\section{REFERENCES}

[1] Bayhan, G., Dalgic, G. (2012). "Liseyi Terk Eden Öğrencilerin Tecrübelerine Göre Lise Terki" [High School Dropout According to the Experiences of Students Who Dropped-out], İnönü Üniversitesi Eğitim Fakültesi Dergisi, 13(3), 107-130, December.

[2] Bennett, R. (2003). Determinants of undergraduate student dropout rates in a university business studies department. Journal of Further and Higher Education, 27(2), 123-141.

[3] Bülbül, T. (2012). Yükseköğretimde Okul Terki: Nedenler ve Çözümler [School Dropout in Higher Education: Reasons and Solutions], Eğitim ve Bilim, 37(166), 219-235.

[4] Chen, R. (2008). Financial aid and student dropout in higher education: A Heterogeneous research approach. In J C. Smart (Eds.), Higher education: Handbook of theory and research (pp. 209-239). New York: Springer Science + Business Media B.V.

[5] Creswell, J.W., Clark, V.L.P. (2011). Designing and conducting mixed methods research $\left(2^{\text {nd }}\right.$ ed $)$, Thousand Oaks, CA, Sage Publications.

[6] Europe Commissioner of Education and Culture. (2015). Dropout and Completion in Higher Education in Europe: Short Country Reports. Luxemburg: Publications Office of the European Union.

[7] OECD. (2016). Education at a Glance: OECD Indic ators. OECD Publishing.

[8] Simșek, H. (2013). Üniversite Öğrencilerinin Okulu Bırakma Eğilimleri ve Nedenleri [Reasons and Tendencies for School Dropout among University 
Students], Afyon Kocatepe Üniversitesi, Kuramsal Eğitimbilim Dergisi, 6(2), 242-271.

[9] Şimşek, H., Katıtaş, S. (2012). İlköğretim İkinci Kademe Öğrencilerinde Okulu Bırakma Eğilimi ve Nedenleri (Şanlıurfa İli Örneği) [Tendency and Reasons of Dropping Out of Secondary School Students], Abant İzzet Baysal Üniversitesi Eğitim Fakültesi Dergisi, 12(2).

[10] Taylı, A. (2008). Okulu Bırakmanın Önlenmesi ve Önlemeye Yönelik Uygulamalar [Prevention of School Dropouts and Preventive Practices], Abant İzzet Baysal Üniversitesi Eğitim Fakültesi Dergisi, 8(1).

[11] Taylı, A. (2008). Eğitim Sisteminde Önemli Bir Sorun:
Okulu Birakma [An Important Problem in the Education System: School Dropouts], Türk Psikolojik Danışma ve Rehberlik Dergisi, 3(30).

[12] Tinto, V. (1975). "Dropout from Higher Education: Theoretical Synthesis of Recent Research". Review of Educational Research, 45(1), pp. 89-125.

[13] Yildırım, A. ve Şimşek, H. (2013). Sosyal bilimlerde nitel araştırma yöntemleri [Qualitative research methods in social sciences]. (9th ed.) Ankara: Seçkin Yayıncılık.

[14] Council of Higher Education (CoHE). Üniversite Listesi [List of Universities]. Retrieved: $20^{\text {th }}$ of June 2017, from http://www.yok.gov.tr/web/guest/universitelerimiz 